\title{
Neighbouring metal induced oxidative addition at the iron centre amongst the iron-arylpyridylphosphine complexes
}

\author{
Olalere G. Adeyemi ${ }^{\mathrm{a}, \mathrm{b}, *}$, Ling-Kang Liu ${ }^{\mathrm{a}, \mathrm{c}}$ \\ a Department of Chemical Sciences, College of Natural Sciences, Redeemer's University, KM 46, Lagos-Ibadan Expressway, Redemption City, Nigeria \\ ${ }^{\mathrm{b}}$ Institute of Chemistry, Academia Sinica, Nankang, Taipei 11529, Taiwan, ROC \\ ${ }^{\mathrm{c}}$ Department of Chemistry, National Taiwan University, Taipei 10767, Taiwan, ROC
}

\section{A R T I C L E I N F O}

\section{Article history:}

Received 28 March 2008

Received in revised form 24 April 2008

Accepted 24 April 2008

Available online 6 May 2008

\section{Keywords:}

Oxidative addition

Hydrides

Iron complexes

Arylpyridylphosphines

\begin{abstract}
A B S T R A C T
Complexes of the type $\left(\eta^{4}-\mathrm{BuC}_{5} \mathrm{H}_{5}\right) \mathrm{Fe}(\mathrm{CO})_{2}(\mathbf{P})\left(\mathbf{P}=\mathrm{PPh}_{2} \mathrm{Py} \mathbf{3}, \mathrm{PPhPy}_{2} 4, \mathrm{PPy}_{3} \mathbf{5} ; \mathrm{Py}=2\right.$-pyridyl $)$ were satisfactorily prepared. Upon treatment of $\mathbf{3}$ with $\mathrm{M}(\mathrm{CO})_{3}(\mathrm{EtCN})_{3}(\mathrm{M}=\mathrm{Mo}, \mathbf{6 a} ; \mathrm{W}, \mathbf{6 b})$, the pyridyl N-atom could be coordinated to the metal $\mathrm{M}$, which then eliminates a $\mathrm{CO}$ ligand from the Fe-centre and induced an oxidative addition of the endo- $\mathrm{C}-\mathrm{H}$ of $\left(\eta^{4}-\mathrm{BuC}_{5} \mathrm{H}_{5}\right)$. This results in a bridged hydrido heterodimetallic complex $\left[\left(\eta^{5}-\mathrm{BuC}_{5} \mathrm{H}_{4}\right) \mathrm{Fe}(\mathrm{CO})\left(\mu-P, N-\mathrm{PPh}_{2} \mathrm{Py}\right)(\mu-\mathrm{H}) \mathrm{M}(\mathrm{CO})_{4}\right](\mathrm{M}=\mathrm{Mo}, \mathbf{7 a}, 81 \% ; \mathrm{W}, \mathbf{7 b}, 76 \%)$. The reaction of $\mathbf{4}$ or $\mathbf{5}$ with $\mathbf{6 a}, \mathbf{b}$ did not give the induced oxidative addition, although these complexes contain more than one pyridyl N-atom. The reaction of $\mathbf{4}$ with $\mathrm{M}(\mathrm{CO})_{4}(\mathrm{EtCN})_{2}(\mathrm{M}=\mathrm{Mo}, \mathbf{9 a} ; \mathrm{W}, \mathbf{9 b})$ produced heterodimetallic complexes $\left.\left[\left(\eta^{4}-\mathrm{BuC}_{5} \mathrm{H}_{5}\right) \mathrm{Fe}(\mathrm{CO})_{2}\left(\mu-P: N, N^{\prime}-\mathrm{PPhPy}\right)_{2}\right) \mathrm{M}(\mathrm{CO})_{4}\right](\mathrm{M}=\mathrm{Mo}, \mathbf{1 0 a}, 81 \%$; W, 10b, 83\%). Treatment of 5 with 6a,b gave $\left[\left(\eta^{4}-\mathrm{BuC}_{5} \mathrm{H}_{5}\right) \mathrm{Fe}(\mathrm{CO})_{2}\left(\mu-P: N, N^{\prime}, N^{\prime \prime}-\mathrm{PPy}\right) \mathrm{M}(\mathrm{CO})_{3}\right](\mathrm{M}=\mathrm{Mo}, \mathbf{1 2 a}, 96 \%$; $\mathrm{W}, \mathbf{1 2 b}$, $78 \%)$.
\end{abstract}

() 2008 Elsevier B.V. All rights reserved.

\section{Introduction}

The coordination chemistry of arylpyridylphosphines $\mathrm{PPh}_{3-n} \mathrm{Py}_{n}$ ( $n=1-3$; Py $=2$-pyridyl) has largely developed. It is of particular interest because of the use of metal complexes containing such ligands in homogeneous catalysis, especially with a potential application in aqueous media [1]. The presence of a basic $\mathrm{N}$-atom in each pendant pyridine in $\mathrm{PPh}_{3-n} \mathrm{Py}_{n}$ ligands distinguishes it from $\mathrm{PPh}_{3}$ ligand. Hence, there is enhanced acid-base chemistry involved by the presence of pyridyl $\mathrm{N}$-atom(s) and more coordination modes are available for $\mathrm{PPh}_{3-n} \mathrm{Py}_{n}$ as ligand than only the $\mathrm{P}$-donor mode in $\mathrm{PPh}_{3}$. For instance, $\mathrm{PPh}_{2} \mathrm{Py}$ could behave in mononuclear complexes as a P-donor ligand and in dinuclear complexes as a $P, N$-bridging ligand with or without metal-metal bonding. $\mathrm{PPhPy}_{2}$ and $\mathrm{PPy}_{3}$ can bind further with a variety of coordination modes: through two pyridyl groups $\left(N, N^{\prime} ; \mathrm{PPh}_{2} \mathrm{Py}\right.$ and $\left.\mathrm{PPy}_{3}\right)$, through three pyridyl groups $\left(N, N^{\prime}, N^{\prime \prime} \mathrm{PPy}_{3}\right)$, and via the phosphorus and two pyridyl groups $\left(P, N, N^{\prime} ; \mathrm{PPhPy}_{2}\right.$ and $\left.\mathrm{PPy}_{3}\right)[2]$.

Few years ago we reported the synthesis of $\left(\eta^{4}-\mathrm{BuC}_{5} \mathrm{H}_{5}\right) \mathrm{Fe}-$ $(\mathrm{CO})_{2}\left(\mathrm{PPh}_{3-n} \mathrm{Py}_{n}\right)(n=1-3)$. A three-component reaction was utilized to produce the complexes. The hydride abstraction of endo-

\footnotetext{
* Corresponding author. Address: Department of Chemical Sciences, College of Natural Sciences, Redeemer's University, KM 46, Lagos-Ibadan Expressway, Redemption City, Nigeria. Tel.: +234 8055516450.

E-mail addresses: drlereadeyemi@yahoo.com, adeyemio@run.edu.ng (O.G. Adeyemi).
}

hydrogen of $\left(\eta^{4}-\mathrm{BuC}_{5} \mathrm{H}_{5}\right) \mathrm{Fe}(\mathrm{CO})_{2}\left(\mathrm{PPh}_{3-\mathrm{n}} \mathrm{Py}_{n}\right)$ were smoothly carried out by Lewis acid, $\mathrm{HBF}_{4} \cdot \mathrm{OEt}_{2}$ to give $\left[\left(\eta^{5}-\mathrm{BuC}_{5} \mathrm{H}_{4}\right) \mathrm{Fe}\right.$ $\left.(\mathrm{CO})_{2}\left(\mathrm{PPh}_{3-\mathrm{n}} \mathrm{Py}_{n}\right)\right]^{+}\left[\mathrm{BF}_{4}\right]^{-}(n=1-2)[3]$.

In this paper, we incorporated the $\mathrm{PPh}_{3-n} \mathrm{Py}_{n}$ ligands into complexes of the type $\left(\eta^{4}-\mathrm{BuC}_{5} \mathrm{H}_{5}\right) \mathrm{Fe}(\mathrm{CO})_{2}\left(\mathrm{PPh}_{3-n} \mathrm{Py}_{n}\right)$ and studied the effect of the presence of the dangling pyridyl $\mathrm{N}$-atom(s), known to be able to coordinate to a second metal centre [2]. In the case of the $\mathrm{PPh}_{2}$ Py complex which contains one pyridyl N-atom, a neighbouring Mo or W metal originally with three labile ligands could induce an oxidative addition on the Fe-centre. Similar chemistry could not be observed for the $\mathrm{PPhPy}_{2}$ and $\mathrm{PPy}_{3}$ analogues.

\section{Experimental}

\subsection{General}

All manipulations were performed under an atmosphere of prepurified nitrogen with standard Schlenk techniques and a doublefold vacuum line. All solvents were distilled from an appropriate drying agent [4]. For instance, THF, $\mathrm{Et}_{2} \mathrm{O}$ and $n$-hexane were dried over sodium benzophenone ketal. $\mathrm{CH}_{3} \mathrm{CN}$ and $\mathrm{CH}_{3} \mathrm{CH}_{2} \mathrm{CN}$ were dried over $\mathrm{P}_{2} \mathrm{O}_{5}$ and $\mathrm{CaH}_{2}$ was used for $\mathrm{CH}_{2} \mathrm{Cl}_{2}$. Infrared spectra were recorded in $\mathrm{CH}_{2} \mathrm{Cl}_{2}$ using $\mathrm{CaF}_{2}$ optics on a Perkin-Elmer (FT-IR) Paragon 1000 spectrophotometer. The ${ }^{1} \mathrm{H}$ NMR and ${ }^{13} \mathrm{C}$ NMR spectra were obtained on Bruker AC200/AC300 spectrometers, with chemical shifts reported in $\delta$ values, downfield positive, relative to the residual solvent resonance of $\mathrm{CDCl}_{3}\left({ }^{1} \mathrm{H} \delta 7.24,{ }^{13} \mathrm{C}\right.$ 
NMR $\delta$ 77.0). The ${ }^{31} \mathrm{P}$ NMR spectra were obtained on Bruker AC200/ AC300 spectrometers using $85 \% \mathrm{H}_{3} \mathrm{PO}_{4}$ as an external standard $(\delta$ $0.00)$. The melting points were determined on a Yanaco MPL melting-point apparatus and are uncorrected. Mass spectra were recorded on a VG 70 - 250S mass Spectrometer, using fast atomic bombardment technique, independently operated by the Institute of Chemistry, Academia Sinica. Chemical analysis was performed on a Perkin-Elmer $2400 \mathrm{CHN}$ elemental analyzer, also independently operated by the Institute of Chemistry, Academia Sinica. Compounds 1, [5], 2, 3, 4, 5 [3], 6a,b, [6] and 9a,b [7] were prepared according to literature procedure. Ligands $\mathrm{PPh}_{2} \mathrm{Py}$ [8a], $\mathrm{PPhPy}_{2}$ [8b], $\mathrm{PPy}_{3}[8 \mathrm{c}]$ were prepared using $\mathrm{Li}-\mathrm{Br}$ exchange method in good yield. $\mathrm{PC}_{3}, \mathrm{PPhC}_{2}, \mathrm{PPh}_{2} \mathrm{C} 1$, and $o-\mathrm{C}_{5} \mathrm{H}_{4} \mathrm{NBr}$ were obtained from commercial sources, distilled twice and degassed prior to use. Other reagents were obtained from commercial sources and used without further purification.

\section{2. $\left[\left(\eta^{5}-\mathrm{BuC}_{5} \mathrm{H}_{4}\right) \mathrm{Fe}(\mathrm{CO})\left(\mu-\mathrm{P}: \mathrm{N}-\mathrm{PPh}_{2} \mathrm{Py}\right)(\mu-\mathrm{H}) \mathrm{Mo}(\mathrm{CO})_{4}\right] \mathbf{7 a}$}

Compound $3(0.30 \mathrm{~g}, 0.60 \mathrm{mmol})$ reacted with $6 \mathbf{a}(0.30 \mathrm{~g}$, $0.87 \mathrm{mmol})$ and were dissolved in dry THF $(30 \mathrm{~mL})$. The mixture was warmed up to ensure complete dissolution, to give orange solution. The mixture was then stirred at room temperature for $2 \mathrm{~h}$ to give a deep orange solution which was filtered via a pad of dry celite under nitrogen and washed with dry ether until colourless to give clear orange solution. The solvent was removed under vacuum. The ensuing orange solid was dissolved in a little quantity of $\mathrm{CH}_{2} \mathrm{Cl}_{2}$ and mixed well with a little quantity of $\mathrm{Al}_{2} \mathrm{O}_{3}$ before being pack on a short $\mathrm{Al}_{2} \mathrm{O}_{3}$ column. The orange band was eluted with 1:8-1:5 EtOAc/n-hexane mixtures. Bright orange powder of $7 \mathbf{a}$ was collected after removing the solvent under vacuum.

Compound 7a: yield: $0.33 \mathrm{~g}$, $81 \%$; mp: $111^{\circ} \mathrm{C}$ (dec.); $\mathrm{IR}\left(\mathrm{CH}_{2} \mathrm{Cl}_{2}\right)$ $v_{\mathrm{CO}} 2016$ (m), 1927 (vs), 1896 (s), 1879 (sh), 1830 (s) cm $\mathrm{cm}^{-1} ;{ }^{31} \mathrm{P}$ NMR $\left(\mathrm{CDCl}_{3}\right) \delta 86.12(\mathrm{~s}) ;{ }^{1} \mathrm{H}$ NMR $\left(\mathrm{CDCl}_{3}\right) \delta 9.25$ (b, $\left.1 \mathrm{H}, \mathrm{Py}\right)$, 6.93-7.68 $(\mathrm{m}, 13 \mathrm{H}, \mathrm{Ph}$ and $\mathrm{Py}), 4.75,4.66,4.41,4.30(4 \times \mathrm{b}$, $4 \times 1 \mathrm{H}, \quad \mathrm{Cp}), \quad 0.87-2.42(\mathrm{~m}, 9 \mathrm{H}, \mathrm{Bu}),-16.46(\mathrm{~d}, 1 \mathrm{H}, \mu-\mathrm{H}$, $\left.{ }^{2} J_{\mathrm{PH}}=56 \mathrm{~Hz}\right) ; \mathrm{MS} m / z 678\left(\mathrm{M}^{+}+1\right)$. Anal. Calc. for $\mathrm{C}_{31} \mathrm{H}_{28} \mathrm{FeMoNO}{ }_{5} \mathrm{P}$ : C, 54.95; H, 4.14; N, 2.07. Found: C, 55.24; H, 4.85; N 1.77\%.

\section{3. $\left[\left(\eta^{5}-\mathrm{BuC}_{5} \mathrm{H}_{4}\right) \mathrm{Fe}(\mathrm{CO})\left(\mu-\mathrm{P}: \mathrm{N}-\mathrm{PPh}{ }_{2} \mathrm{Py}\right)(\mu-\mathrm{H}) \mathrm{W}(\mathrm{CO})_{4}\right] \mathbf{7 b}$}

Compound 3 ( $0.30 \mathrm{~g}, 0.60 \mathrm{mmol})$ and $\mathbf{6 b}(0.30 \mathrm{~g}, 0.69 \mathrm{mmol})$ were dissolved in dry THF $(30 \mathrm{~mL})$. The procedure is similar to that of the reaction of the molybdenum analogue except that the purification was carried out using a silica gel column. The orange solid was dissolved in a small quantity of $\mathrm{CH}_{2} \mathrm{Cl}_{2}$ and mixed well with a small quantity of silica gel before being packed on top of a silica gel column, and then eluted with a EtOAc/n-hexane mixture. The orange powder of $\mathbf{7 b}$ was collected after solvent removal under vacuum.

Compound 7b: yield: $0.35 \mathrm{~g}, 76 \%$, mp: $120{ }^{\circ} \mathrm{C}$ (dec.); IR $\left(\mathrm{CH}_{2} \mathrm{Cl}_{2}\right)$ $v_{\mathrm{CO}} 2009$ (m), 1927 (s) 1886 (vs, b), 1827 (s) $\mathrm{cm}^{-1} ;{ }^{31} \mathrm{P}$ NMR $\left(\mathrm{CDC1}_{3}\right) \delta 88.6(\mathrm{~s}) ;{ }^{1} \mathrm{H}$ NMR $\left(\mathrm{CDC1}_{3}\right) \delta 9.38(\mathrm{~b}, 1 \mathrm{H}, \mathrm{Py}), 6.90-7.48$ $(\mathrm{m}, 13 \mathrm{H}, \mathrm{Ph}$ and $\mathrm{Py}), 4.77,4.72,4.51,4.31(4 \times \mathrm{b}, 4 \times 1 \mathrm{H}, \mathrm{Cp})$, $0.87-2.63(\mathrm{~m}, 9 \mathrm{H}, \mathrm{Bu}),-14.21\left(\mathrm{~d}, 1 \mathrm{H}, \mu-\mathrm{H},{ }^{2} \mathrm{~J}_{\mathrm{PH}}=54 \mathrm{~Hz}\right) ; \mathrm{MS} m / z$ $766\left(\mathrm{M}^{+}+1\right)$. Anal. Calc. $\mathrm{C}_{31} \mathrm{H}_{28} \mathrm{FeNO}_{5} \mathrm{PW}: \mathrm{C}, 48.63 ; \mathrm{H}, 3.66 ; \mathrm{N}$, 1.83. Found: C, $48.78 ; \mathrm{H}, 3.98 ; \mathrm{N}, 1.75 \%$.

\section{4. $\left[\left(\eta^{4}-\mathrm{BuC}_{5} \mathrm{H}_{5}\right) \mathrm{Fe}(\mathrm{CO})_{2}\left(\mu-P: N, N^{\prime}-P P h P y_{2}\right) \mathrm{Mo}(\mathrm{CO})_{4}\right] \mathbf{1 0 a}$}

Compound $4(0.10 \mathrm{~g}, 0.20 \mathrm{mmol})$ and $9 a(0.10 \mathrm{~g}, 0.31 \mathrm{mmol})$ were completely dissolved in dry THF $(10 \mathrm{~mL})$. The colour changed to blood red immediately. The mixture was allowed to stir for $1.5 \mathrm{~h}$ before filtration over a bed of dry celite under nitrogen. The solvent was removed under vacuum and the red solid re-crystallized twice with ether $/ n$-hexane mixture $(1: 1)$ and filtered to give a brick red solid of 10a. Using $\left(\mathrm{C}_{7} \mathrm{H}_{8}\right) \mathrm{Mo}(\mathrm{CO})_{4}\left(80 \mathrm{mg}, 0.27 \mathrm{mmol}, \mathrm{C}_{7} \mathrm{H}_{8}=\right.$ bicyclo $[2,2]$ hepta-2,5-diene) to replace $\mathbf{9 a}$, the result is the same with very similar yields.

Compound 10a: yield: $0.114 \mathrm{~g}, 81 \%, \mathrm{mp}: 138{ }^{\circ} \mathrm{C}$ (dec.); IR $\left(\mathrm{CH}_{2} \mathrm{Cl}_{2}\right) \quad v_{\mathrm{CO}} 1977$ (s), 1919 (vs) 1816 (s, b) cm ${ }^{-1} ;{ }^{31} \mathrm{P}$ NMR $\left(\mathrm{CDC}_{3}\right) \delta 95.5(\mathrm{~s}) ;{ }^{1} \mathrm{H}$ NMR $\left(\mathrm{CDC}_{3}\right) \delta 9.24$ (b, $\left.2 \mathrm{H}, \quad \mathrm{Py}\right)$, ${ }^{4} J_{\mathrm{PH}}=4.95 \mathrm{~Hz}, 6.53-8.30(\mathrm{~m}, 11 \mathrm{H}, \mathrm{Ph}$ and $\mathrm{Py}), 4.95(\mathrm{~b}, 2 \mathrm{H}$, $-\mathrm{CH}=\mathrm{CHCHBu}-), 2.49$ (b, $1 \mathrm{H},-\mathrm{CH}=\mathrm{CHCHBu}-), 2.22$ (b, $2 \mathrm{H}$ $-\mathrm{CH}=\mathrm{CHCHBu}-), \quad 0.51-1.08 \quad(\mathrm{~m}, \quad 9 \mathrm{H}, \quad \mathrm{Bu}), \quad \mathrm{MS}(\mathrm{m} / z) 497$ $\left(\mathrm{M}^{+}-\mathrm{Mo}(\mathrm{CO})_{4}+1\right), 441\left(\mathrm{M}^{+}-\mathrm{Mo}(\mathrm{CO})_{6}+1\right)$. Anal. Calc. $\mathrm{C}_{31} \mathrm{H}_{27} \mathrm{FeMo}-$ $\mathrm{N}_{2} \mathrm{O}_{6} \mathrm{P}: \mathrm{C}, 52.69 ; \mathrm{H}, 3.82 ; \mathrm{N}, 3.97$. Found: $\mathrm{C}, 52.16 ; \mathrm{H}, 4.43 ; \mathrm{N}$, $3.65 \%$.

\section{5. $\left[\left(\eta^{4}-\mathrm{BuC}_{5} \mathrm{H}_{5}\right) \mathrm{Fe}(\mathrm{CO})_{2}\left(\mu-P: N, N^{\prime}-P P h P y_{2}\right) W(\mathrm{CO})_{4}\right]$ 10b}

The procedure is similar to that of the reaction of the molybdenum analogue with $4(0.30 \mathrm{~g}, 0.60 \mathrm{mmol})$ and $9 \mathbf{b}(0.30 \mathrm{~g}$, $0.74 \mathrm{mmol})$ in dry THF $(10 \mathrm{~mL})$. Dark purple solid of 10b was collected after the necessary work-up.

Compound 10b : yield: $0.40 \mathrm{~g}, 83 \%$; mp: $143{ }^{\circ} \mathrm{C}$ (dec.); IR $\left(\mathrm{CH}_{2} \mathrm{C1}_{2}\right) v_{\mathrm{CO}} 1977$ (s), 1912 (vs) 1813 (s, b) $\mathrm{cm}^{-1} ;{ }^{31} \mathrm{P}$ NMR $\left(\mathrm{CDC1}_{3}\right) \delta 97.9(\mathrm{~s}) ;{ }^{1} \mathrm{H}$ NMR $\left(\mathrm{CDC1}_{3}\right) \delta 9.30$ (b, 2H, Py), 6.40-8.28 $(\mathrm{m}, 11 \mathrm{H}, \mathrm{Ph}$ and $\mathrm{Py}), 4.98(\mathrm{~b}, 2 \mathrm{H},-\mathrm{CH}=\mathrm{CHCHBu}-), 2.52(\mathrm{~b}, 1 \mathrm{H},-$ $\mathrm{CH}=\mathrm{CHCHBu}-), 2.29(\mathrm{~b}, 2 \mathrm{H},-\mathrm{CH}=\mathrm{CHCHBu}-), 0.56-1.06(\mathrm{~m}, 9 \mathrm{H}$ $\mathrm{Bu}), \mathrm{MS} m / z 767\left(\mathrm{M}^{+}-\mathrm{CO}+1\right) 497,\left(\mathrm{M}^{+}-\mathrm{W}(\mathrm{CO})_{4}+1\right)$. Anal. Calc. for $\mathrm{C}_{31} \mathrm{H}_{27} \mathrm{FeN}_{2} \mathrm{O}_{6} \mathrm{PW}$ : C, 46.85; H, 3.40; N, 3.53. Found: C, 46.32; $\mathrm{H}$, 3.66; N, 3.33\%.

\section{6. $\left[\left(\eta^{4}-\mathrm{BuC}_{5} \mathrm{H}_{5}\right) \mathrm{Fe}(\mathrm{CO})_{2}\left(\mu-P: N, N^{\prime} N^{\prime \prime}-P P y_{3}\right) \mathrm{Mo}(\mathrm{CO})_{3}\right] \mathbf{1 2 a}$}

Compound 5 ( $0.20 \mathrm{~g}, 0.40 \mathrm{mmol})$ and $6 \mathbf{6 a}(0.20 \mathrm{~g}, 0.58 \mathrm{mmol})$ were completely dissolved in dry THF $(20 \mathrm{~mL})$. The mixture turned purple immediately. The reaction was left for $1 \mathrm{~h}$ before being filtered under nitrogen through a pad of dry celite and washed with dry ether until colourless. The solvent was removed under vacuum, resulting in a dark purple solid, which was dissolved in a small quantity of $\mathrm{CH}_{2} \mathrm{Cl}_{2}$ and mixed completely with a small quantity of alumina. The $\mathrm{CH}_{2} \mathrm{Cl}_{2}$ was removed under vacuum. The residue was packed on top of an alumina column and then eluted with a 3:1 EtOAc/n-hexane mixture. A deep purple solid 12a was collected.

Compound 12a: yield: $0.26 \mathrm{~g}, 96 \%$; mp: $158^{\circ} \mathrm{C}$ (dec.); IR $\left(\mathrm{CH}_{2} \mathrm{Cl}_{2}\right) v_{\mathrm{CO}} 1981(\mathrm{~m}), 1924(\mathrm{~m}), 1905(\mathrm{vs}), 1788(\mathrm{~s}, \mathrm{~b}) \mathrm{cm}^{-1}$; ${ }^{31} \mathrm{P} \mathrm{NMR}\left(\mathrm{CDC1}_{3}\right) \delta 75.4(\mathrm{~s}) ;{ }^{1} \mathrm{H}$ NMR $\left(\mathrm{CDC1}_{3}\right) \delta 9.47$ (b, 3H), 8.48 (b, 3H), $7.85(\mathrm{~b}, 3 \mathrm{H}), 7.20(\mathrm{~b}, 3 \mathrm{H})$ for pyridine, $5.35(\mathrm{~b}, 2 \mathrm{H}$, $\mathrm{CH}=\mathrm{CHCHBu}-), 3.27$ (b, $2 \mathrm{H},-\mathrm{CH}=\mathrm{CHCHBu}-), 3.04(\mathrm{~b}, 1 \mathrm{H},-$ $\mathrm{CH}=\mathrm{CHCHBu}-), 0.83-1.15(\mathrm{~m}, 9 \mathrm{H}, \mathrm{Bu}), \mathrm{MS} m / z 498\left(\mathrm{M}^{+}-\mathrm{Mo}(\mathrm{CO})_{3}\right)$. Anal. Calc. $\mathrm{C}_{29} \mathrm{H}_{25} \mathrm{FeMoN}_{3} \mathrm{O}_{5} \mathrm{P}$ : C, 51.33; $\mathrm{H}, 3.69 ; \mathrm{N}, 6.19$. Found: $\mathrm{C}$, 50.38; H, 3.95; N, 5.73\%.

\section{7. $\left[\left(\eta^{4}-\mathrm{BuC}_{5} \mathrm{H}_{5}\right) \mathrm{Fe}(\mathrm{CO})_{2}\left(\mu-P: N, N^{\prime} N^{\prime \prime}-P P y_{3}\right) W(\mathrm{CO})_{3}\right] \mathbf{1 2 b}$}

Compound 5 (0.20 g, $0.40 \mathrm{mmol})$ and $\mathbf{6 b}(0.20 \mathrm{~g}, 0.46 \mathrm{mmol})$ were dissolved in dry THF $(10 \mathrm{~mL})$. Again the mixture immediately changed to purple colour. The reaction was then left for $2 \mathrm{~h}$. Other procedure and work-up were similar to those used in the molybdenum analogue.

Compound 12b: yield: $0.24 \mathrm{~g}, 78 \%$; mp: $165{ }^{\circ} \mathrm{C}$ (dec.); IR $\left(\mathrm{CH}_{2} \mathrm{C1}_{2}\right) v_{\mathrm{CO}} 1982(\mathrm{~m}), 1926$ (s), 1895 (vs), $1782(\mathrm{~s}, \mathrm{~b}) \mathrm{cm}^{-1} ;{ }^{31} \mathrm{P}$ NMR $\left(\mathrm{CDC1}_{3}\right) \delta 77.2(\mathrm{~s}) ;{ }^{1} \mathrm{H}$ NMR $\left(\mathrm{CDC1}_{3}\right) \delta 9.48(\mathrm{~b}, 3 \mathrm{H}) 8.50$ (b, 3H), $7.88(\mathrm{~b}, 3 \mathrm{H}), 7.15(\mathrm{~b}, 3 \mathrm{H})$ for pyridine, $5.38(\mathrm{~b}, 2 \mathrm{H}$, $-\mathrm{CH}=\mathrm{CHCHBu}-), 3.31$ (b, $2 \mathrm{H},-\mathrm{CH}=\mathrm{CHCHBu}-), 3.06(\mathrm{~b}, 1 \mathrm{H}$, $-\mathrm{CH}=\mathrm{CHCHBu}-$ ), 0.82-1.24 (m, 9H, Bu); $\mathrm{MS} \mathrm{m} / z 498\left(\mathrm{M}^{+}-\mathrm{W}(\mathrm{CO})_{3}\right)$. Anal. Calc. for $\mathrm{C}_{29} \mathrm{H}_{25} \mathrm{FeN}_{3} \mathrm{O}_{5} \mathrm{PW}$ : C, 45.43; H, 3.26; N, 5.43. Found: C, $44.98 ; \mathrm{H}, 3.63 ; \mathrm{N}, 5.00 \%$. 


\section{Results and discussion}

\subsection{Preparation of arylpyridylphosphine ligands}

The preparation of $\mathrm{PPh}_{3-n} \mathrm{Py}_{n}(n=1-3)$ followed the literature procedures but with a slight local modification $[8 \mathrm{a}, 8 \mathrm{~b}, 8 \mathrm{c}]$. In our own experience, the preparation of $\mathrm{PPhPy}_{2}$ gave a yield of $19.7 \%$ when the Grignard reagent on the pyridyl side is used for coupling with $\mathrm{PPhCl}_{2}$. The preparation of $\mathrm{PPhPy}_{2}$ gave a much better yield of $54.5 \%$ by using the $\mathrm{Li}-\mathrm{Br}$ exchange reaction between $n$-BuLi and $o-$ $\mathrm{C}_{5} \mathrm{H}_{4} \mathrm{NBr}$, then the coupling reaction with $\mathrm{PPhC}_{2}$. The preparation of $\mathrm{PPh}_{3-n} \mathrm{Py}_{n}(n=1-3)$ in the present study involved the $n$-BuLi route and the yields were satisfactory $\left(\mathrm{PPh}_{2} \mathrm{Py}, 82 \% ; \mathrm{PPhPy}_{2}, 55 \%\right.$; $\left.\mathrm{PPy}_{3}, 62 \%\right)$. Pure $\mathrm{PPy}_{3}$ was stored in the dry box in order to avoid oxidation of the phosphine to $\mathrm{Py}_{3} \mathrm{P}=\mathrm{O}$.

\section{2. $\left(\eta^{4}-\mathrm{Bu} \mathrm{C}_{5} \mathrm{H}_{5}\right) \mathrm{Fe}(\mathrm{CO})_{2}\left(\mathrm{PPh}_{3-n} \mathrm{Py} y_{n}\right)$ complexes}

The arylpyridylphosphine ligands were reacted with a stoichiometric amount of $\left(\eta^{5}-\mathrm{C}_{5} \mathrm{H}_{5}\right) \mathrm{Fe}(\mathrm{CO})_{2} \mathrm{I}$ (1) and a slight excess amount of $n$-BuLi, using the same conditions as those used in the preparation of $\left(\eta^{4}-\mathrm{BuC}_{5} \mathrm{H}_{5}\right) \mathrm{Fe}(\mathrm{CO})_{2}\left(\mathrm{PPh}_{3}\right)(2)$ [3]. With one basic $\mathrm{N}$-atom in each pendant pyridine, the arylpyridylphosphines reacted smoothly in the three-component reaction and gave similarly $\left(\eta^{4}-\mathrm{BuC}_{5} \mathrm{H}_{5}\right) \mathrm{Fe}(\mathrm{CO})_{2}\left(\mathrm{PPh}_{3-n} \mathrm{Py}_{n}\right)$ in good yields of relevant complexes $(\mathbf{3}, n=1,68 \% ; \mathbf{4}, n=2,72 \% ; \mathbf{5}, n=3,74 \%)$. The chemistry followed the same pathway as in the $\mathrm{PPh}_{3}$ case [3].

Scheme 1 shows the two stages in the three-component preparation of compounds $\mathbf{2 - 5}$. The first drop of $n$-BuLi acted as a reducing agent [9] to initiate an electron-transfer chain catalysis [10] of the replacement of iodide on 1 by $\mathrm{PPh}_{3-n} \mathrm{Py}_{n}$ with the P-donor mode. The cation $\left[\left(\eta^{5}-\mathrm{C}_{5} \mathrm{H}_{5}\right) \mathrm{Fe}(\mathrm{CO})_{2}\left(\mathrm{PPh}_{3-n} \mathrm{Py}_{n}\right)^{+}\right] \quad(n=0-4)$ is instantaneously obtained in this reaction [11]. The stoichiometric $n$-BuLi then acts as a normal nucleophile to add on to the $\left(\eta^{5}\right.$ $\left.\mathrm{C}_{5} \mathrm{H}_{5}\right)$-ring [12,13]. The electron rich $\left(\eta^{5}-\mathrm{C}_{5} \mathrm{H}_{5}\right)$-ring of neutral $\mathbf{1}$ did not react with the electron rich $\left[\mathrm{Bu}^{-}\right]$anion in an ordinary way. In its cationic form, the $\left(\eta^{5}-\mathrm{C}_{5} \mathrm{H}_{5}\right)$-ring is more likely activated as a Lewis-acid. [ $\left.\left(\eta^{5}-\mathrm{C}_{5} \mathrm{H}_{5}\right) \mathrm{Fe}(\mathrm{CO})_{2}\left(\mathrm{PPh}_{3-n} \mathrm{Py}_{n}\right)^{+}\right]$is much more electrophilic towards $\left[\mathrm{Bu}^{-}\right]$and the addition of $\left[\mathrm{Bu}^{-}\right]$anion on the $\left(\eta^{5}-\mathrm{C}_{5} \mathrm{H}_{5}\right)$-ring is favoured [3].

\subsection{Heterodimetallic complexes}

In the main synthetic routes to organo-transition metal hydrides, the intramolecular oxidative addition is a key to the facile loss of hydrogen, for example, in $\left(\eta^{4}-\mathrm{C}_{5} \mathrm{H}_{6}\right) \mathrm{Fe}(\mathrm{CO})_{3}$ which proceeds with an intermediate formation of $\left(\eta^{5}-\mathrm{C}_{5} \mathrm{H}_{5}\right) \mathrm{Fe}(\mathrm{CO})_{2} \mathrm{H}$, to finally yield $\left.\left(\eta^{5}-\mathrm{C}_{5} \mathrm{H}_{5}\right) \mathrm{Fe}(\mathrm{CO})_{2}\right]_{2}$ [14]. Yet, it is possible to independently synthesize $\left(\eta^{5}-\mathrm{C}_{5} \mathrm{H}_{5}\right) \mathrm{Fe}(\mathrm{CO})_{2} \mathrm{H}$ from the acidification of $\left(\eta^{5}\right.$ $\left.\mathrm{C}_{5} \mathrm{H}_{5}\right) \mathrm{Fe}(\mathrm{CO})_{2} \mathrm{Na}$. In the literature, it was not synthesized directly

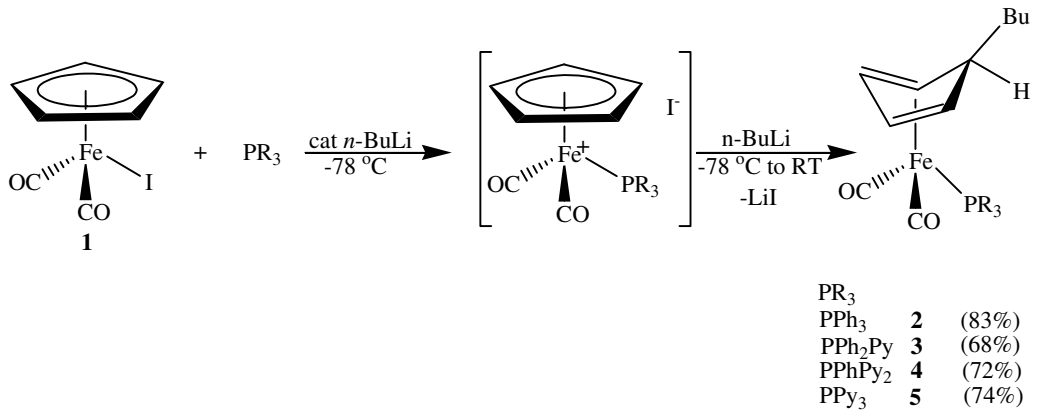

Scheme 1.
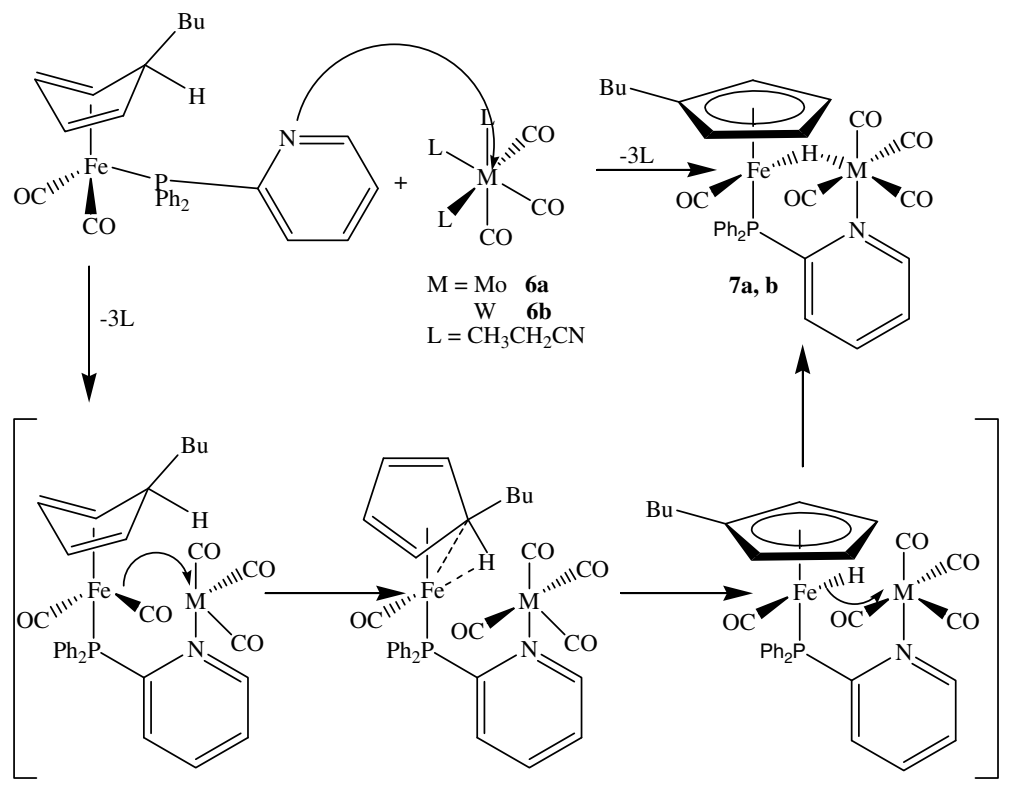

Scheme 2 . 
from $\left(\eta^{4}-\mathrm{C}_{5} \mathrm{H}_{6}\right) \mathrm{Fe}(\mathrm{CO})_{3}$ due to competing and/or consecutive reactions [15].

We discuss below a clean activation of the endo-C- $\mathrm{H}$ bond of 3 that was formally a ( $\eta^{4}$-cyclopentadiene)-Fe complex in $\mathrm{PPh}_{2} \mathrm{Py}$ derivative. When 3 is reacted with $\mathrm{M}(\mathrm{CO})_{3}(\mathrm{EtCN})_{3}(\mathrm{M}=\mathrm{Mo}, \mathbf{6 a}$; $\mathrm{W}, \mathbf{6 b}$ ) with the labile EtCN to be replaced by the pyridyl $\mathrm{N}$-atom and others, the result is the hydridobridged heterodimetallic complex $\left[\left(\eta^{5}-\mathrm{BuC}_{5} \mathrm{H}_{4}\right) \mathrm{Fe}(\mathrm{CO})\left(\mu-P: N-\mathrm{PPh}_{2} \mathrm{Py}\right)(\mu-\mathrm{H}) \mathrm{M}(\mathrm{CO})_{4}\right](\mathrm{M}=\mathrm{Mo}, 7 \mathbf{a}$, 81\%; W, 7b, 76\%) with six-membered heterocyclic ring (Scheme 2).

The environments around $\mathrm{Fe}$ and $\mathrm{M}$ in $\mathbf{7 a} \mathbf{a}, \mathbf{b}$ changed substantially from the starting environments of $\mathbf{3}$ and $\mathbf{6 a}, \mathbf{b}$ as shown by the complete disappearance of all the original IR $v_{\mathrm{CO}}$ bands: the 1966 (s) $\mathrm{cm}^{-1}$ bands for the two CO ligands connected to Fe in $\mathbf{3}$, the 1921 (s), 1801 (s) $\mathrm{cm}^{-1}$ for the three CO ligands connected to Mo in 6a, and the 1910 (s), 1793 (s) $\mathrm{cm}^{-1}$ for the three CO ligands connected to $\mathrm{W}$ in $\mathbf{6 b}$. The ${ }^{1} \mathrm{H}$ NMR data also indicated that the 2:1:2 integration ratios for the $\left(\eta^{4}-\mathrm{BuC}_{5} \mathrm{H}_{5}\right)$ fragment of 3 disappeared. Whereas a 4-peak, equal-intensity pattern characteristic of a $\left(\eta^{5}-\mathrm{BuC}_{5} \mathrm{H}_{4}\right)$ connected to a chiral metal centre appeared ( $c f$. at $\delta 4.75,4.66,4.41,4.30$ in $7 \mathbf{a}$ and at $\delta 4.77,4.72,4.51,4.31$ in 7b). The doublet hydrides at $\delta-16.5$ with ${ }^{2} J_{\mathrm{PH}}=56 \mathrm{~Hz}$ in $7 \mathbf{a}$ and at $\delta-14.2$ with ${ }^{2} \mathrm{~J}_{\mathrm{PH}}=54 \mathrm{~Hz}$ in $\mathbf{7 b}$ were observed in the ${ }^{1} \mathrm{H}$ NMR spectra. The molecular structure of $\mathbf{7 a , b}$ was finalized on the basis of a similar compound $\left[\left(\eta^{4}-\mathrm{MeC}_{5} \mathrm{H}_{4}\right) \mathrm{Fe}(\mathrm{CO})\left(\mu-P: P^{\prime}-\mathrm{PPh}_{2} \mathrm{CH}_{2} \mathrm{PPh}_{2}\right)\right.$ $\left.(\mu-\mathrm{H}) \mathrm{M}(\mathrm{CO})_{4}\right](\mathrm{M}=\mathrm{Mo}$ and $\mathrm{W})[16]$ that was prepared from $\mathbf{6 a}, \mathbf{b}$ and a $\left[\left(\eta^{4}-\mathrm{MeC}_{5} \mathrm{H}_{5}\right) \mathrm{Fe}(\mathrm{CO})_{2}\left(\eta^{1}-\mathrm{PPh}_{2} \mathrm{CH}_{2} \mathrm{PPh}_{2}\right)\right.$ with the dangling $\mathrm{PPh}_{2}$ working the same way as the present pyridyl $\mathrm{N}$-atom. The dppm analogue revealed very similar spectroscopic data in the IR and ${ }^{1} \mathrm{H}$ NMR spectra to those of $\mathbf{7 a}, \mathbf{b}$, especially those of the hydride and $\left(\eta^{5}-\mathrm{MeC}_{5} \mathrm{H}_{4}\right)$ ligands connected to a chiral metal centre. Earlier, the origin of the hydride and additional $\mathrm{CO}$ on M-centre of $\left[\left(\eta^{5}-\mathrm{MeC}_{5} \mathrm{H}_{4}\right) \mathrm{Fe}(\mathrm{CO})\left(\mu-P: P^{\prime}-\mathrm{PPh}_{2} \mathrm{CH}_{2} \mathrm{PPh}_{2}\right)(\mu-\mathrm{H}) \mathrm{M}(\mathrm{CO})_{4}\right] \quad(\mathrm{M}=\mathrm{Mo}$ and W) [16] was assigned as intramolecularly converted from the endo- $\mathrm{H}$ and the $\mathrm{CO}$ on Fe-centre, based on quantitative yield during synthesis. The hydride remained un-changed with the deuterium atoms of $d$-solvent when the reaction was performed in $d^{8}$-THF. It is pertinent to state that, crystal suitable for X-ray crystallography for these compounds was attempted, but did not succeed.

Apparently in Scheme 2, it shows that, upon pyridyl N-atom ligation to the second metal $(\mathrm{M}=\mathrm{Mo}, \mathrm{W})$, this neighbouring metal $\mathrm{M}$ induces an oxidative addition of the endo- $\mathrm{C}-\mathrm{H}$ of cyclopentadiene on the initial Fe-centre, by taking away a $\mathrm{CO}$ ligand from the Fe-centre. Originally the Fe-centre in $\mathbf{3}$ is penta-coordinate. The loss of $\mathrm{CO}$ to $\mathrm{M}$-centre results in a tetra-coordinate $\mathrm{Fe}(0)$, ready to activate the nearby endo $\mathrm{C}-\mathrm{H}$ bond. Along the reaction coordinate, $\mathrm{Fe}(0)$ then changes to a hexa-coordinate $\mathrm{Fe}(\mathrm{II})$. At a later stage, the second metal $\mathrm{M}$ traps the newly formed $\mathrm{Fe}-\mathrm{H}$ bond in the form of " $3 c-2 e$ " $\mathrm{M}-\mathrm{H}-\mathrm{Fe}$ structure. The relative conformation with respect to $\mathrm{Fe}$ and $\mathrm{M}$ is not yet clear during the stage of the pyridyl $\mathrm{N}$-atom ligation or during the stage of the CO-migration. The final conformation with respect to $\mathrm{Fe}$ and $\mathrm{M}$ is in a syn-form in $7 \mathbf{a}, \mathbf{b}$.

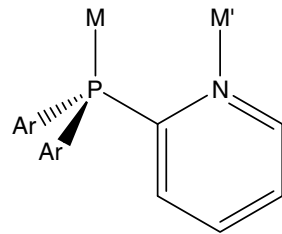

syn-form<smiles></smiles>

anti-form
Drawings of syn- and anti- forms<smiles>O=[N+]([O-])[C@@](O)(c1ccccc1)[P](c1ccccn1)(c1ccccn1)c1ccccn1</smiles>

4

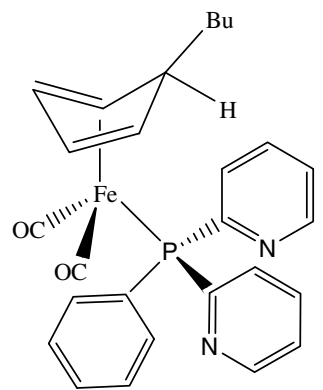

4

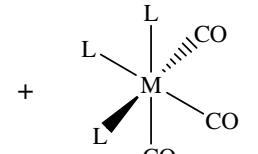
$\mathrm{CO}$

$6 a, b$

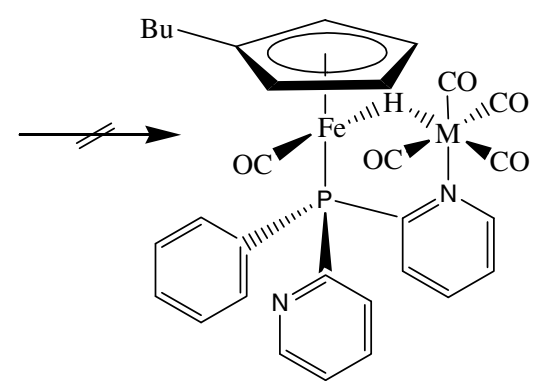

8a, b

$+\mathrm{CO}(1 \mathrm{~atm})$

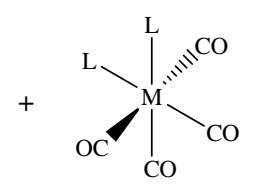

$M=$ Mo 9a

W 9b $\mathrm{L}=\mathrm{CH}_{3} \mathrm{CH}_{2} \mathrm{CN}$

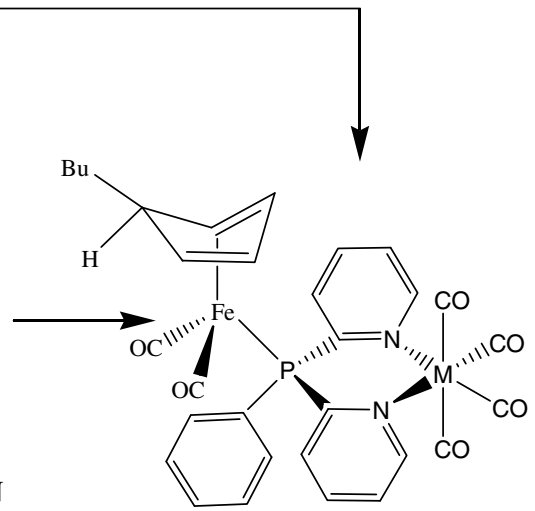

10a, b 


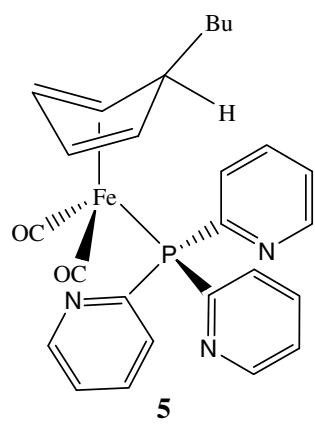

$$
\begin{aligned}
& \mathrm{M}=\underset{\mathrm{Mo}}{\mathrm{Wa}} \\
& \mathrm{L}=\mathrm{CH}_{3} \mathrm{CH}_{2} \mathrm{CN}
\end{aligned}
$$

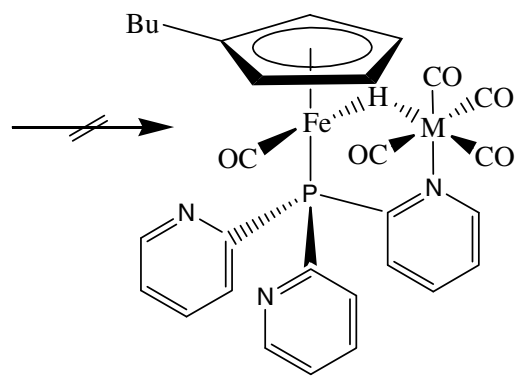

11a, b

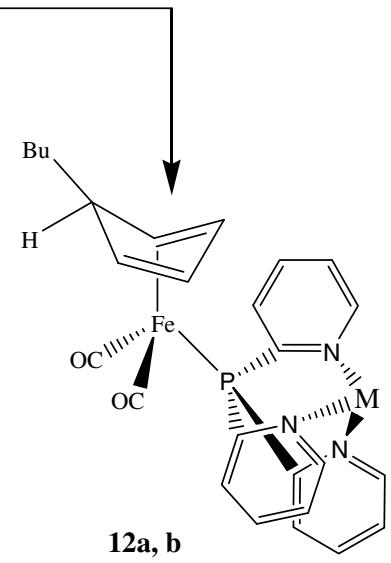

Scheme 4.

With two pyridyl $\mathrm{N}$-atoms, $\mathbf{4}$ gave no hydride formation when it was reacted with $\mathbf{6 a}, \mathbf{b}$. There was no spectroscopic evidence to support the structure $\left[\left(\eta^{5}-\mathrm{BuC}_{5} \mathrm{H}_{4}\right) \mathrm{Fe}(\mathrm{CO})\left(\mu-P: N-\mathrm{PPhPy}_{2}\right)(\mu-\mathrm{H})-\right.$ $\left.\mathrm{M}(\mathrm{CO})_{4}\right]$ ( $\left.\mathrm{M}=\mathrm{Mo}, \mathbf{8 a} ; \mathrm{W}, \mathbf{8 b}\right)$ (Scheme 3).

When 4 was treated with $\mathrm{M}(\mathrm{CO})_{4}(\mathrm{EtCN})_{2}(\mathrm{M}=\mathrm{Mo}, \mathbf{9 a} ; \mathrm{W}, \mathbf{9 b})$ as shown in Scheme 3, the $N, N^{\prime}$-chelated heterodimetallic complex was collected in high yield, i.e., $\left[\left(\eta^{4}-\mathrm{BuC}_{5} \mathrm{H}_{5}\right) \mathrm{Fe}(\mathrm{CO})_{2}\left(\mu-P: N, N^{\prime}-\right.\right.$ $\left.\left.\mathrm{PPhPy}_{2}\right) \mathrm{M}(\mathrm{CO})_{4}\right](\mathrm{M}=\mathrm{Mo}, 10 a, 81 \% ; \mathrm{W}, 10 \mathrm{~b}, 83 \%)\left(\mathrm{C}_{7} \mathrm{H}_{8} \mathrm{Mo}(\mathrm{CO})_{4}\right.$ $\left(\mathrm{C}_{7} \mathrm{H}_{8}=\right.$ bicyclo $[2,2]$ hepta-2,5-diene $)$ replacing 9a gave the same result). Alternative route to the synthesis of $\mathbf{1 0 a}, \mathbf{b}$ was achieved when CO (1 atm) was bubbled into the solution of $\mathbf{4}$ and $\mathbf{6 a}, \mathbf{b}$ to produce variable yields of $\mathbf{1 0 a}, \mathbf{b}$.

The reaction of $\mathbf{5}$ and $\mathbf{6 a}, \mathbf{b}$ shown in Scheme 4, did not give compound $\left[\left(\eta^{5}-\mathrm{BuC}_{5} \mathrm{H}_{4}\right) \mathrm{Fe}(\mathrm{CO})\left(\mu-P: N-\mathrm{PPy}_{3}\right)(\mu-\mathrm{H}) \mathrm{M}(\mathrm{CO})_{4}\right] \quad(\mathrm{M}=\mathrm{Mo}$, 11a; $\mathrm{W}, 11 \mathrm{~b})$, but the $N, N^{\prime} \mathrm{N}^{\prime \prime}$-coordinated heterodimetallic complex $\left[\left(\eta^{4}-\mathrm{BuC}_{5} \mathrm{H}_{5}\right) \mathrm{Fe}(\mathrm{CO})_{2}\left(\mu-P: N, N^{\prime}, N^{\prime \prime}-\mathrm{PPy}_{3}\right) \mathrm{M}(\mathrm{CO})_{3}\right] \quad(\mathrm{M}=\mathrm{Mo}$, 12a, 96\%; W, 12b, 78\%).

The IR $v_{\mathrm{CO}}$ data for the two CO ligands connected to Fe exhibit a shift to higher wave numbers upon attachment of $\mathrm{M}(\mathrm{CO})_{3}$ to the three pyridyl $\mathrm{N}$-sites of $\mathrm{PPy}_{3}$, i.e., from $1969,1909 \mathrm{~cm}^{-1}$ in $\mathbf{5}$ to $1981,1924 \mathrm{~cm}^{-1}$ in 12a and 1982, $1926 \mathrm{~cm}^{-1}$ in $\mathbf{1 2 b}$. Upon attachment of $\mathrm{M}(\mathrm{CO})_{4}$ to the two pyridyl $\mathrm{N}$-sites of $\mathrm{PPhPy}_{2}$, similar shifts are found in 10a,b, to $1977,1919 \mathrm{~cm}^{-1}$ and $1977,1912 \mathrm{~cm}^{-1}$, respectively, comparing with $1967,1907 \mathrm{~cm}^{-1}$ in 4 . It was observed that, complexes $\mathbf{1 0 a}, \mathbf{b}$ and 12a were not excellently stable when expose to air. This could attributes to high values recorded for carbon in the elemental analysis results.

\section{Conclusion}

Organo-transition metal hydrides could be produced through the intramolecular oxidative addition reaction between endo-C- $\mathrm{H}$ of cyclopentadiene iron with one pyridyl $\mathrm{N}$-atom and $\mathrm{M}(\mathrm{CO})_{3} \mathrm{~L}_{3}$ ( $\mathrm{M}=\mathrm{Mo}, \mathrm{W} ; \mathrm{L}=$ labile ligand). Yet, there is no hydride formation with complexes of more than one pyridyl N-atoms e.g. $\left(\eta^{4}-\right.$ $\left.\mathrm{BuC}_{5} \mathrm{H}_{5}\right) \mathrm{Fe}(\mathrm{CO})_{2}\left(\mathrm{PPhPy}_{2}\right)$ and $\left(\eta^{4}-\mathrm{BuC}_{5} \mathrm{H}_{5}\right) \mathrm{Fe}(\mathrm{CO})_{2}\left(\mathrm{PPy}_{3}\right)$. The CO transfer from Fe to $\mathrm{M}$ shown in Scheme 2 is more likely to be the slow step than the pyridyl N-ligation to $\mathrm{M}$, to the state, ready for oxidative addition of $\mathrm{Fe}(0)$ in the reaction coordinate. Apparently, in $\mathbf{4}$ and $\mathbf{5}$, extra pyridyl $\mathrm{N}$-atom(s) are involved to mask the migration of CO ligand from Fe-centre to M-centre. Accordingly, these two compounds do not exhibit an induced activation of the endo$\mathrm{C}-\mathrm{H}$ bond of the cyclopentadiene on Fe-centre.

\section{Acknowledgement}

Thanks are due to the National Science Council and Academia Sinica for the kind financial support.

\section{References}

[1] (a) A. Steiner, D. Stalke, Organometallics 14 (1995) 2422;

(b) G.R. Newkome, Chem. Rev. 93 (1993) 2067;

(c) Y. Xie, C.L. Lee, Y. Yang, S.J. Rettig, B.R. James, Can. J. Chem. 70 (1992) 751;

(d) P. Espinet, K. Soulantica, Coord. Chem. Rev. 193-195 (1999) 499-556.

[2] (a) J.A. Casares, P. Espinet, R. Hernando, G. Ituobe, F. Villafane, Inorg. Chem. 36 (1997) 44;

(b) C. Abu-Gnium, I. Amer, J. Mol. Catal. 85 (1993) L275;

(c) S. Gladiali, L. Pinna, C.G. Arena, E. Rotondo, F. Faraone, J. Mol. Catal. 66 (1991) 183;

(d) R. Gregorzik, J. Wirbser, H. Vahrenkamp, Chem. Ber. 125 (1991) 1575; (e) F.R. Kenn, M.R. Snow, P.J. Stephenson, E.R.T. Tiekink, Inorg. Chem. 27 (1988) 2040;

(f) J.P. Farr, M.M. Olmstead, F.E. Wood, A.L. Balch, J. Am. Chem Soc. 105 (1983) 792;

(g) M.M. Olmstead, A. Maisonnet, J.P. Farr, A.L. Balch, Inorg. Chem. 20 (1981) 4060; 
(h) K. Boggess, D.A. Zatko, J. Coord. Chem. 4 (1975) 217

(i) R.P. Schutte, S.J. Rettig, A.M. Joshi, B.R. James, Inorg. Chem. 36 (25) (1997) 5809.

[3] (a) L.-K. Liu, L.-S. Luh, Organometallics 13 (1994) 2816;

b) L.-S. Luh, L.-K. Liu, Bull. Inst. Chem., Acad. Sin. 41 (1994) 39;

(c) L.-K. Liu, L.-S. Luh, P.-C. Chao, Y-T.Y.-T. Fu, Bull. Inst. Chem., Acad. Sin. 42 (1995) 1

(d) L.-S. Luh, U.B. Eke, L.-K. Liu, Organometallics 14 (1995) 440;

(e) L.-S. Luh, L.-K. Liu, Organometallics 14 (1995) 1514;

(f) O.G. Adeyemi, L.-K. Liu, Synth. React. Inorg. Met. - Org. Chem. 31 (2001) 737.

[4] D.D. Perrin, W.L.F. Armarego, D.R. Perrin, Purification of Laboratory Chemicals, Pergamon Press, Oxford, UK, 1981.

[5] (a) B.D. Dombek, R.J. Angelici, Inorg. Chim. Acta 7 (1973) 345;

b) T.J. Meyer, E.C. Johnson, N. Winterton, Inorg. Chem. 10 (1971) 1673;

(c)Inorg. Synth. 12 (1971) 36;

(d)Inorg. Synth. 7 (1963) 110;

(e) R.B. King, M.B. Bisnette, J. Organomet. Chem. 2 (1964) 15.

6] G.J. Kubas, Inorg. Chem. 22 (1983) 692.

[7] W. Strohmeier, G. Schonauer, Chem. Ber. 94 (1961) 1346.

[8] (a) A. Maisonnet, J.P. Farr, M.M. Olmstead, C.T. Hunt, A.L. Balch, Inorg. Chem. 21 (1982) 3961

(b) F.G. Mann, J. Watson, J. Org. Chem. 13 (1948) 502

(c) K. Kurtev, D. Ribola, R.A. Jones, D.J. Cole-Hamilton, G. Wilkinson, J. Chem Soc., Dalton Trans. 56 (1980).
[9] (a) L.-K. Liu, Y.H. Liao, U.B. Eke, Organometallics 18 (1999) 1154;

(b) E.C. Ashby, T.N. Pham, B. Park, Tetrahedron Lett. 26 (1985) 4691;

(c) H. Yamataka, N. Fujimura, Y. Kawafuji, T. Hanafusa, J. Am. Chem. Soc. 109

(1987) 4305;

(d) P.M. Treichel, R.L. Shubkin, Inorg. Chem. 6 (1967) 1328;

(e) M.Y. Darensbourg, J. Organomet. Chem. 38 (1972) 133.

[10] (a) D. Austruc, Electron Transfer and Radical Process in Transition Meta Chemistry, VCH, Weinheim, Germany, 1995;

(b) O.G. Adeyemi, L. -K.L.-K. Liu, Inorg. Chim. Acta 360 (2007) 2464

[11] (a) L.-K. Liu, U.B. Eke, M.A. Mesubi, Organometallics 14 (1995) 3958;

(b) S.L. Gipson, L.-K. Liu, R.U. Soliz, J. Organomet. Chem. 526 (1996) 393;

(c) Z. Liu, S.L. Gipson, J. Organomet. Chem. 553 (1998) 269;

(d) L.-K. Liu, Bull. Inst. Chem., Acad. Sin. 46 (1999) 31.

[12] F.A. Cotton, G. Wilkinson, Advanced Inorganic Chemistry, 5th ed., Wiley, New York, 1988. pp. 58-61.

[13] M.M. Rahman, H.-Y. Liu, K. Eriks, A. Prock, W.P. Giering, Organometallics 8 (1989) 1. and references therein for quantitative analysis of ligand effects.

[14] (a) C. Elschenbroich, A. Salzer, Organometallics, 2nd ed., VCH, Weinheim, Germany, 1992;

(b) A. Davison, M.L.H. Green, G. Wilkinson, J. Chem. Soc. (1961) 3172;

(c) R.K. Kochlar, R. Pettit, J. Organomet. Chem. 6 (1966) 272;

(d) T.H. Whitesides, J. Shelly, J. Organomet. Chem. 92 (1975) 215

[15] T.A. Shackleton, S.C. Mackie, S.B. Fergusson, L.J. Johnson, M.C. Baird, Organometallics 9 (1990) 2248. and relevant references therein..

[16] C.W. Liu, Y.-S. Wen, L.-K. Liu, Organometallics 16 (1997) 155. 